cholesterol, blood pressure, smoking, and age. The differences between the Minnesota and Framingham groups are in the main those of interpretation rather than fact. Epidemiological considerations alone cannot decide how much emphasis we should place on avoidance of obesity in preventing coronary disease.

Energy balance and adipose tissue mass may influence serum lipid metabolism independently. ${ }^{29}$ Olefsky et $a l^{30}$ found that when an isocaloric diet of unchanged composition was resumed by individuals who had reduced their weight by dieting there was a substantial fall in both cholesterol and triglyceride concentrations attributed to decreased lipoprotein synthesis. The effects of energy balance are themselves complex. Do serum lipids respond to changes in energy intake irrespective of the source, or does the effect depend upon which nutrients are consumed to excess? There is some evidence that the effects of fat, carbohydrate, and alcohol are independent. ${ }^{29}$ Clearer answers to this question will help frame an optimum policy for reduction of serum lipid concentrations in the community. Certainly in the treatment of pronounced hyperlipidaemia treatment must be individual. ${ }^{29}$

Many years ago Keys et $a l^{31}$ reported on the range of individual responsiveness to dietary fat; Mistry et $a l^{32}$ have recently observed that the response of serum lipoproteins to dietary cholesterol varies widely from person to person. In dogs fed cholesterol both the increase in serum lipids and the development of atherosclerosis seem to be under genetic influence. ${ }^{33}$ Studies have begun on the metabolic basis of common forms of hyperlipidaemia, ${ }^{34}{ }^{35}$ and will need to be coupled with investigation of their interaction with diet before we can hope to understand the mechanisms of "multifactorial" hyperlipidaemia.

1 Stamler, J, Berksom, D M, and Lindberg, H A, in The Pathogenesis of Atherosclerosis, eds R W Wissler and J C Geer, chapter 3. Baltimore, Williams and Wilkins, 1972.

${ }^{2}$ Goto, Y, Sato, S-I, and Masuda, M, Tohoku fournal of Experimental Medicine, 1974, 112, 339.

${ }^{3}$ Keys, A, Circulation, 1970, 41-42 suppl 1.

4 Trowell, H, American fournal of Clinical Nutrition, 1972, 25, 926.

5 Lewis, B, et al, Lancet, 1974, 1, 141.

- Morris, J N, et al, British Medical fournal, 1963, 1, 571.

7 Stulb, S C, et al, American fournal of Clinical Nutrition, 1965, 16, 238.

${ }^{8} \mathrm{Kahn}, \mathrm{H}$ A, et al, Israel fournal of Medical Sciences, 1969, 5, 1117.

- Kannel, W B, and Gordon, T, The Framingham Study: An Epidemiological Investigation of Cardiovascular Disease Section 24, 1970. Bethesda, US National Heart Institute.

10 Nichols, A B, et al, fournal of the American Medical Association, 1976, 236, 1948.

11 Easty, D L, British Fournal of Nutrition, 1970, 24, 307.

12 Gossage, A M, Quarterly Fournal of Medicine, 1908, 1, 331.

13 Goldstein, J L, et al, fournal of Clinical Investigation, 1973, 52, 1544.

14 Slack, J, in Atherosclerosis 3, eds G Schettler and A Weizel, p 415. Berlin, Springer, 1974.

15 Schaefer, L E, Adlersberg, D, Steinberg, A G, Circulation, 1958, 17, 537.

${ }^{16}$ Johnson, B C, Epstein, F H, and Kjelsberg, M O, fournal of Chronic Diseases, 1965, 18, 147.

17 Godfrey, R C, et al, Australian Paediatric fournal, 1972, 8, 72.

18 Osborne, R H, et al, American fournal of Medicine, 1959, 26, 54.

10 McDonough, J R, et al, Circulation, 1962, 25, 962.

20 Jensen, J, et al, fournal of Lipid Research, 1965, 6, 193.

21 Pikkarainen, J, Takkunen, J, and Kulonen, E, American fournal of Human Genetics, 1966, 18, 115.

22 Rifkind, B M, et al, Cardiovascular Research, 1968, 2, 148.

${ }^{23}$ Deutscher, S, Ostrander, L D, and Epstein, F H, American fournal of Epidemiology, 1970, 91, 233.

24 Patterson, D, Slack, J, Lancet, 1972, 1, 393.

25 Epstein, F H, Postgraduate Medical fournal, 1976, 52, 477.

${ }^{26}$ Kannel, W B, et al, Circulation, 1967, 35, 734.

27 Kannel, W B, and Gordon, T, The Framingham Study: An Epidemiological Investigation of Cardiovascular Disease Sections 5, 1968; 26 and 27, 1971. Bethesda, US National Heart Institute.

${ }^{28}$ Ashley, F W Jr, and Kannel, W B, fournal of Chronic Disease, 1974, 27, 103.

${ }^{29}$ Lewis, B, The Hyperlipidaemias: Clinical and Laboratory Practice. Oxford, Blackwell, 1976.

30 Olefsky, J, Reaven, G M, and Farquhar, J W, fournal of Clinical Investigation, 1974, 53, 64 .

31 Keys, A, Anderson, J T, and Grande, F, Circulation, 1959, 19, 201.
${ }^{32}$ Mistry, P, et al, Circulation, 1976, 54, suppl 11-178 (abstract).

${ }^{33}$ Mahley, R W, Weisgraber, K H, and Innerarity, T, Circulation Research, $1974,35,722$.

${ }^{34}$ Goldstein, J L, and Brown, M S, fournal of Laboratory and Clinical Medicine, 1975, 85, 15.

35 Sigurdsson, G, Nicoll, A, and Lewis, B, European fournal of Clinical Investigation, 1976, 6, 167.

\section{Delusions of parasitosis}

Patients with delusions of parasitosis have an erroneous but unshakable belief that their skin is infested by a parasite. This description is preferable to the older term "acarophobia," since most patients do not actually fear infestation by acari: they are certain that they are infested with a variety of insects, which in one instance amounted to ten different species. ${ }^{1}$

The typical patient with delusions of parasitosis is a woman over 40 (the condition is three times as common in women) who regards doctors and nurses with suspicion and antagonism. Early in the consultation she produces a twist of paper or other container which holds fragments of skin such as rolled up keratin, crusts, or miscellaneous debris. She then gives a detailed description of how the supposed parasites have been caught in the act of burrowing, biting, or otherwise harming her. Occasionally they may have been trapped on the furniture. She may well have already called in the health authorities to disinfest her house on more than one occasion. She will complain also of sensations which vary from simple pruritus to burning, gnawing, crawling, or biting.

The skin may appear normal, but there is usually evidence of picking or scratching and sometimes dermatitis from the strong antiseptics which have been used to try and rid herself of the organism. Any suggestion that she could be mistaken is violently opposed, and the possibility of a psychiatric consultation is adamantly rejected and, indeed, is likely to cause her not to attend again.

The incidence of the disorder is difficult to assess since patients refuse to attend hospital, but it is probably more common than published work would suggest. Schrut and Waldron $^{2}$ saw over 100 cases in five years. Wilson and Miller ${ }^{1}$ reviewed 51 case histories, and Wilson ${ }^{3}$ described 34 more patients six years later. Only five of those 34 attended a psychiatrist, and none were cured. The condition seems as common in Britain as in North America: Tullett ${ }^{4}$ noted that 25 such patients had been seen at St John's Hospital for Diseases of the Skin in London in ten years. The delusion may be shared by more than one member of the family, particularly husband and wife, but one of the most remarkable examples was a family of parents and two daughters who sold three suites of "infected furniture" and changed houses eight times in 10 years. ${ }^{5}$

Considerable difficulty exists in placing the patients in any distinct psychiatric category. Paranoid schizophrenia in an elderly age group or monosymptomatic hypochrondriasis occurring in an obsessional personality have been suggested. ${ }^{4}$ Hopkinson ${ }^{6}$ pointed out that there was a clear-cut difference in the type of case referred to a dermatologist. Those who were referred direct to a psychiatrist were more likely to have a recognisable psychiatric entity such as an affective disorder or schizophrenia. Rarely pellagra ${ }^{7}$ and vitamin $B_{12}$ deficiency ${ }^{8}$ may present in this way.

The management of such a patient who attends a skin clinic and who refuses to accept psychiatric help is extremely difficult, 
but Gould and $\mathrm{Gragg}^{9}$ have recently suggested some guidelines. The diagnosis must be correct, so that the first essential has to be a physical examination to exclude organic disease and the possibility of true infestation. Wilson ${ }^{3}$ described one woman with a bizarre story compatible with a delusional state who was found to have pediculosis capitis. Gould and Gragg ${ }^{9}$ advise listening to the patient without argument, attempting to build up trust and a positive bond. They advocate trying to reduce the patient's sense of isolation and the use of psychoactive drugs to lessen the patient's anxiety.

Whether treated by dermatologist or psychiatrist the prognosis for recovery is poor, and some patients have remained deluded for 20 years. $^{1}$

\footnotetext{
${ }^{1}$ Wilson, J W, and Miller, H E, Archives of Dermatology and Syphilology, $1946,54,39$.

2 Schrut, A H, and Waldron, W G, fournal of the American Medical Association, 1963, 186, 429.

3 Wilson, J W, Archives of Dermatology and Syphilology, 1952, 66, 577.

4 Tullett, G L, British fournal of Dermatology, 1965, 77, 448.

5 Evans, P, and Merskey, H, British fournal of Medical Psychology, 1972, 45,

6 Hopkinson, G, Psychiatria Clinica, 1973, 6, 330.

7 Aleshire, I, fournal of the American Medical Association, 1954, 155, 15.

* Pope, F M, Practitioner, 1970, 204, 421.

${ }^{9}$ Gould, W M, and Gragg, T M, Archives of Dermatology, 1976, 112, 1745.
}

\section{Difficulties in leukaemia diagnosis}

Early attempts at chemotherapy in leukaemia suggested that the response of acute lymphoblastic leukaemia (ALL) was better than that of acute nonlymphoid leukaemia. Since then, diagnosis has been shown to be vital in determining both prognosis and treatment. While many acute leukaemias can be typed, ${ }^{12}$ there remains a group sometimes described (inappropriately) as acute undifferentiated leukaemia where exact diagnosis is difficult. In these cases the blast cells may be primitive precursors of myeloblasts or lymphoblasts, and they are difficult to recognise, though cytochemical procedures ${ }^{3}$ may help to separate them. Bennett $e t a^{1}$ found that some of the blast cells in all patients with myeloid leukaemia stained positively with myeloperoxidase or Sudan Black B, the positive reaction being particularly helpful in distinguishing this group from patients with lymphoblastic leukaemia. They also found help from fluoride-sensitive non-specific esterase stains, which give a positive reaction in most monocytic, granulocytic, and myelomonocytic leukaemias. Monocytoid cells usually show a very strong reaction which is inhibited by sodium fluoride. In cells of myeloid origin, on the other hand, the reaction is unaffected by fluoride and in lymphoblasts the reaction is negative.

Simple cytochemistry may, then, help in the diagnosis of all acute nonlymphoid leukaemias but may give only negative help in ALL, in which identifying antigens on the cell surface of lymphoblasts ${ }^{4-6}$ is the key. While some $70 \%$ of the blast cells do not carry B- or T-cell markers, they do react with antisera specific for ALL; and, of the rest, $28 \%$ carry Tlymphocyte markers and rare patients (about 3\%) have blasts of B-cell origin.

Recently a small but important group of patients has been identified who present with the clinical and morphological features of ALL, but in whom further evidence suggests that the correct diagnosis is chronic myeloid leukaemia (CML) presenting in blast cell crisis without any previous detectable chronic phase. ${ }^{7}$ These patients have minor changes in the peripheral blood not seen in ALL, including the Pelger-Huët anomaly in the shape of nuclei, hypogranular neutrophils, and primitive monocytoid cells. In fact, the true diagnosis has been established only when the Philadelphia chromosome has been identified.

The Philadelphia chromosome is present in about $90 \%$ of patients with CML and may be regarded as a specific marker for the disease, as it occurs only rarely in other conditions. Janossy et $a l^{8}$ examined cell surface markers in 14 patients with the blast cell transformation of CML and showed that some blast cells reacted with a specific ALL antiserum of non-T and non-B cell type and that all showed diminished expression of cholera toxin receptors when compared with granulocytes from the chronic phase of CML. They suggested that the blast cell crisis of CML is morphologically heterogeneous and that in some patients cells develop which are morphologically identical to those seen in most patients with ALL and which cannot be differentiated from ALL blasts by the use of membrane markers.

These findings have practical importance, since the blast cell crisis of CML is often resistant to treatment whereas adult ALL has a better prognosis. Similar clinical and morphological observations have recently been reported in children. ${ }^{9} \mathrm{CML}$ in children is rare, but clearly there have been examples of children presenting in the blast cell phase of CML who were misdiagnosed as having ALL. The much improved prognosis for children with ALL makes accurate diagnosis necessary, and since there is evidence of other karyotypic abnormalities in AML which may be related to poor prognosis ${ }^{10}$ there is a strong case for examining chromosomes in all patients with acute leukaemia. Certainly chromosome analysis should be undertaken in any patient whose blast cells cannot be classified precisely or in any child with ALL who does not enter an early remission.

Leukaemic states described variously as "smouldering leukaemia," "preleukaemia," or "subacute leukaemia" are probably better defined" as "refractory anaemia with excess of blasts" but are difficult to diagnose. Nevertheless, they are usually associated with dyserythropoietic changes in the bone marrow and sometimes with the presence of ring sideroblasts. The peripheral blood may show neutropenia, hypogranular polymorphs, the Pelger-Huët anomaly, and low monocyte counts in association with a hypercellular bone marrow with a varying degree of abnormal granulocyte maturation. The blast cell count is usually $10-20 \%$, and leukaemia can usually be diagnosed with confidence only by showing a progressive increase in blast cells in the blood and bone marrow at repeated examinations.

Recent studies in patients with lymphoid neoplasms have also helped the classification of leukaemia including the separation of several disease states previously collected under the label of chronic lymphatic leukaemia (CLL). Leukaemic reticuloendotheliosis, ${ }^{11}$ sometimes called hairy cell leukaemia, presents at a younger age than CLL with progressive tiredness, moderate to massive splenomegaly, and pancytopenia with variable numbers of abnormal mononuclear cells in the blood. The lymph nodes are usually enlarged, but are seldom prominent. The abnormal cells seen in variable numbers in the peripheral blood and bone marrow may be mistaken for the lymphocytes of CLL. They are distinguished by their abundant cytoplasm; stippled chromatin, in which nucleoli can often be discerned; and particularly by their irregular "hairy" 